\title{
THE EFFECTS OF QUIET STANDING ON SOLUTE DIURESIS ${ }^{1}$
}

\author{
By ALLAN V. N. GOODYER 2 AND DONALD W. SELDIN 3 \\ (From the Department of Medicine, Yale University School of Medicine, New Haven, \\ Connecticut)
}

(Submitted for publication August 1, 1952; accepted December 18, 1952)

\section{INTRODUCTION}

In normal supine human subjects $(1,2)$, the rapid intravenous injection of glucose or mannitol sharply augments the excretion of sodium. Animal experiments indicate that the natriuresis may be mediated at least in large part by a direct renal response to a change in the concentration of the solute in the blood perfusing the kidney (3). It has been suggested that the injected solute restrains the reabsorption of water in the proximal tubules and interferes with the reabsorption of sodium by accelerating the flow of the tubular fluid $(1,3)$, or by diluting the concentration of tubular sodium below that in extracellular water (4). It is implied in these theories that the capacity of the tubular system for sodium transport is either fixed, or only slowly adaptive to changing loads of sodium. It has therefore been of considerable interest to determine the extent to which, and the rapidity with which, internal regulatory factors may counterbalance the intratubular effects of administered solutes. Certain measures which promote the retention of sodium in normal subjects (antecedent salt restriction, or the administration of DOCA) are comparatively ineffective in preventing the sodium diuresis induced by solute loads (5). However, internal regulatory mechanisms in patients with edema severely limit the excretion of sodium despite massive glycosuria (6) even when the renal hemodynamic pattern is essentially normal. It is not clear, therefore, whether the retention of sodium during osmotic diuresis is a unique feature of the edematous state, or whether the stimuli which have been used to promote salt retention in normal subjects are of insufficient intensity.

1 This study has been supported by grants from the American Heart Association and the National Institutes of Health, Public Health Service (Grant No. RG-3076).

2 Markle Scholar in Medical Science.

3 Present address: Southwestern Medical School of the University of Texas, Dallas, Texas.
Since quiet standing constitutes an extremely potent stimulus for sodium and water retention (7-9), the present experiments were undertaken with the following objectives in mind: (1) to determine whether normal subjects, under the intense stimulus to retain sodium imposed by quiet standing, nevertheless develop the usual diuresis of sodium with solute loads; (2) to decide, by means of clearance techniques, whether the effects observed are mediated by changes in glomerular filtration or tubular transport; and (3) to identify, where possible, the changes in the internal environment which may have been conditioning the renal response.

\section{EXPERIMENTAL PROCEDURE}

Control and experimental studies -were carried out in nine young healthy male subjects. Urine and blood were first obtained while the subject was engaged in normal activity (expts. 1 and 2-Table I), or lying supine on an examining table (expts. 2 to $14-$ Tables I and II). Next, several samples of blood and urine were collected during quiet standing (the subject stood at the side of a shelf on which his arms rested, with only such minimal movement of the trunk and extremities as was found necessary to prevent collapse). Finally, several recovery periods were obtained during which the subject again assumed a supine position. In one experiment (Table II, expt. 9) additional periods during quiet standing and recovery in the supine position followed. Urine was collected in all cases by voluntary voiding. In our experience, the error involved in this method, in selected normal young subjects, is small. The possible effect of such an error on the urinary changes observed between periods of low and those of high flow, has been minimized in most cases in these experiments by averaging the data of more than one period of actual urine collection in each of the "periods" designated $A, B, C$, etc., in Tables I and II.

Two types of control studies are summarized in Table I. The effects of quiet standing alone, without solute loading, were studied in three experiments during dehydration and hydration. Table I summarizes the effects of injections of hypertonic solutions of sodium bicarbonate and sodium phosphate ( $\mathrm{pH} 7.4)$ while the subject was supine. Table II summarizes the results of experimental studies of the effects of injections of mannitol and sodium salts during the period of quiet standing. 
Data, in part previously reported by this laboratory $(2,9)$, on the effects of mannitol loads in supine subjects, and of saline infusions in both supine and standing subjects, have also been used in the construction of Table III and Figures 1 and 2.

In six experiments (expts. $3,8,10,11,12,13$ ), glomerular filtration rates were estimated from the clearance of inulin administered as a constant infusion. The isotonic sodium phosphate used in experiments 4 and 14 was prepared as a mixture of $\mathrm{NaH}_{2} \mathrm{PO}_{4}$ and $\mathrm{Na}_{2} \mathrm{HPO}_{4}$ of $\mathrm{pH} 7.4$ (10).

Mannitol in serum and urine was analyzed by the method of Smith (11), modified according to Elkinton (12), inulin by the method of Roe (13), potassium and sodium on a flame photometer, and inorganic phosphate by the method of Fiske and Subbarow (14) as modified for the photoelectric colorimeter. Chloride in the serum was determined by the method of Hald (15), protein by the biuret reaction (16), and total $\mathrm{CO}_{2}$ content by the method of Van Slyke and Neill (17). Urea and ammonia in the urine were determined by the methods of Conway (18), and chloride by a modification of the method of Volhard and Harvey (19). Acute changes in plasma volume were calculated from changes in the hemoglobin and hematocrit as described previously (9). The $\mathrm{pH}$ of serum was determined, with anaerobic precautions, with a glass electrode (Beckman). Because of the difficulties of collecting urine anaerobically under the conditions of these experiments, bicarbonate concentrations in the urine were not directly measured. However, since bicarbonate constitutes the major urinary anion in those experiments in which sodium bicarbonate was infused, changes in the excretion of bicarbonate were estimated from changes in the excretion of "undetermined anions" (calculated according to the formula: $A=[\mathrm{Na}+\mathrm{K}+$ $\mathrm{NH}_{4}$ ] $-\mathrm{Cl}$, where $\mathrm{A}$ is the rate of excretion of "undetermined anions"). In 27 urines collected anaerobically in normal individuals during the infusion of sodium bi-

TABLE I

Control studies. The effects of quiet standing, and of infusions of $\mathrm{NaHCO}_{2}$ and $\mathrm{Na}_{2} \mathrm{HPO}_{4}$, on the serum and urine of normal subjects

\begin{tabular}{|c|c|c|c|c|c|c|c|c|c|c|c|c|c|c|c|c|c|c|c|}
\hline \multirow{2}{*}{ Subject* } & \multirow{2}{*}{$\begin{array}{l}\text { Proce- } \\
\text { dure }\end{array}$} & \multirow{2}{*}{ Periodt } & \multirow{2}{*}{ Time } & \multicolumn{7}{|c|}{ Urine } & \multirow{2}{*}{ GFR } & \multicolumn{7}{|c|}{ Serum $¥$} & \multirow{2}{*}{$\begin{array}{c}\text { Change } \\
\text { in } \\
\text { plasma } \\
\text { vol. } 8\end{array}$} \\
\hline & & & & Flow & $\mathbf{N a}$ & Cl & $\mathbf{K}$ & $\mathbf{N H}_{4}$ & $\mathbf{P} \|$ & $\begin{array}{l}\text { An- } \\
\text { ions: }\end{array}$ & & $\mathbf{N a}$ & Cl & $\mathbf{K}$ & $\mathrm{CO}_{2}$ & Prot. & pH & $\mathbf{P} \|$ & \\
\hline & & no. & mins. & $\underset{\text { min. }}{c c_{.} /}$ & \multicolumn{6}{|c|}{ micro. Eq./min. } & $\underset{\text { min. }}{c c . l}$ & \multicolumn{4}{|c|}{$m E q$. liter } & $\overline{\text { gms. }}$ & & mg. & per cent \\
\hline 1) $A V G$ (a) & $\begin{array}{l}\text { Ambulant } \\
\text { Standing } \\
\text { Supine }\end{array}$ & $\begin{array}{l}\mathbf{A} \\
\mathbf{B}\end{array}$ & $\begin{array}{r}140 \\
63 \\
131\end{array}$ & $\begin{array}{l}0.4 \\
0.2 \\
0.3\end{array}$ & $\begin{array}{r}44.4 \\
4.7 \\
6.8\end{array}$ & $\begin{array}{l}68.0 \\
15.6 \\
19.1\end{array}$ & $\begin{array}{l}39.6 \\
27.2 \\
38.3\end{array}$ & $\begin{array}{l}26.0 \\
19.5 \\
21.3\end{array}$ & & & & $\begin{array}{l}142 \\
138 \\
138\end{array}$ & $\begin{array}{l}101 \\
104 \\
106\end{array}$ & $\begin{array}{l}3.6 \\
3.6 \\
3.7\end{array}$ & & \begin{tabular}{l|}
7.75 \\
7.95 \\
7.05
\end{tabular} & & & $\begin{array}{r}0 \\
-12 \\
+5\end{array}$ \\
\hline 2) DWS (a) & $\begin{array}{l}\text { Ambulant } \\
\text { Supine } \\
\text { Standing } \\
\text { Supine } \\
\text { Supine }\end{array}$ & $\begin{array}{l}\mathbf{A} \\
\mathbf{B} \\
\mathbf{C} \\
\mathbf{D} \\
\mathbf{E}\end{array}$ & $\begin{array}{l}74 \\
64 \\
38 \\
50 \\
69\end{array}$ & $\begin{array}{l}0.6 \\
0.6 \\
0.4 \\
0.2 \\
0.3\end{array}$ & \begin{tabular}{c|}
108 \\
140 \\
81.2 \\
9.1 \\
18.8
\end{tabular} & \begin{tabular}{c|}
125 \\
100 \\
92.0 \\
12.2 \\
27.0
\end{tabular} & $\begin{array}{l}37.4 \\
42.5 \\
38.6 \\
19.0 \\
23.1\end{array}$ & $\begin{array}{r}16.7 \\
13.3 \\
8.0 \\
6.6 \\
8.1\end{array}$ & \begin{tabular}{l|}
13.3 \\
23.5 \\
16.6 \\
11.6 \\
25.8
\end{tabular} & & & $\begin{array}{l}138 \\
140 \\
137 \\
142\end{array}$ & $\begin{array}{l}102 \\
102 \\
102 \\
102\end{array}$ & $\begin{array}{l}3.4 \\
3.5 \\
3.8 \\
3.5\end{array}$ & $\begin{array}{l}27.5 \\
27.0 \\
24.0 \\
27.1\end{array}$ & \begin{tabular}{|l|}
7.92 \\
7.25 \\
8.18 \\
7.54
\end{tabular} & $\begin{array}{l}7.43 \\
7.46 \\
7.49 \\
7.47\end{array}$ & $\begin{array}{l}4.5 \\
4.6 \\
3.8 \\
4.2\end{array}$ & $\begin{array}{r}0 \\
+14 \\
+6 \\
+2\end{array}$ \\
\hline 3) DWS (b) & $\begin{array}{l}\text { Supine } \\
\text { Standing } \\
\text { Supine } \\
\text { Supine }\end{array}$ & $\begin{array}{l}\mathbf{A} \\
\mathbf{B} \\
\mathbf{C} \\
\mathbf{D}\end{array}$ & $\begin{array}{l}66 \\
69 \\
32 \\
86\end{array}$ & $\begin{array}{l}6.8 \\
1.4 \\
1.1 \\
4.7\end{array}$ & $\begin{array}{l}294 \\
210 \\
160 \\
247\end{array}$ & $\begin{array}{l}403 \\
270 \\
230 \\
318\end{array}$ & \begin{tabular}{r|}
102 \\
70.0 \\
57.0 \\
78.5
\end{tabular} & $\begin{array}{l}41.7 \\
37.5 \\
38.3 \\
39.9\end{array}$ & $\begin{array}{l}13.5 \\
12.7 \\
18.7 \\
31.7\end{array}$ & & $\begin{array}{l}161 \\
126 \\
103 \\
140\end{array}$ & $\begin{array}{l}140 \\
141 \\
141 \\
140\end{array}$ & $\begin{array}{l}105 \\
105 \\
105 \\
105\end{array}$ & $\begin{array}{l}5.0 \\
4.9 \\
5.0 \\
5.0\end{array}$ & $\begin{array}{l}25.0 \\
22.4 \\
24.2\end{array}$ & \begin{tabular}{l|}
6.54 \\
6.78 \\
7.22 \\
6.20
\end{tabular} & $\begin{array}{l}7.42 \\
7.38 \\
7.48\end{array}$ & $\begin{array}{l}3.5 \\
3.6 \\
3.6 \\
3.6\end{array}$ & $\begin{array}{r}0 \\
-24 \\
+4\end{array}$ \\
\hline $\begin{array}{l}\text { 4) } \text { H., }_{1} \\
\text { 1 liter, } 1 \% \\
\text { NadHPOH }\end{array}$ & $\begin{array}{l}\text { Supine } \\
\text { Supine } \\
\text { Supine }\end{array}$ & $\begin{array}{l}\mathbf{A} \\
\mathbf{B}_{\mathbf{C}}^{* *}\end{array}$ & $\begin{array}{r}114 \\
116 \\
91\end{array}$ & $\begin{array}{l}3.1 \\
3.8 \\
4.0\end{array}$ & $\begin{array}{c}91.5 \\
161 \\
248\end{array}$ & $\begin{array}{l}83.2 \\
24.2 \\
25.3\end{array}$ & $\begin{array}{l}120 \\
210 \\
203\end{array}$ & $\begin{array}{l}16.4 \\
27.3 \\
21.6\end{array}$ & $\begin{array}{l}53.4 \\
472 \\
584\end{array}$ & & & $\begin{array}{l}139 \\
131 \\
138\end{array}$ & $\begin{array}{l}96.0 \\
93.0 \\
93.3\end{array}$ & $\begin{array}{l}4.3 \\
3.8 \\
3.6\end{array}$ & $\begin{array}{l}26.7 \\
25.9 \\
26.3\end{array}$ & \begin{tabular}{l|}
7.12 \\
6.71 \\
7.00
\end{tabular} & $\begin{array}{l}7.46 \\
7.52 \\
7.49\end{array}$ & $\begin{array}{r}4.5 \\
10.1 \\
10.2\end{array}$ & \\
\hline $\begin{array}{l}\text { 5) } \mathrm{Mac}, \\
600 \mathrm{ccc}^{3} 3.1 \% \\
\mathrm{NaHCO}_{3}\end{array}$ & $\begin{array}{l}\text { Supine } \\
\text { Supine } \\
\text { Supine } \\
\text { Supine }\end{array}$ & $\begin{array}{l}\mathbf{A} \\
\stackrel{B}{C * *} \\
\stackrel{D}{D}\end{array}$ & $\begin{array}{r}108 \\
54 \\
146 \\
225\end{array}$ & $\begin{array}{l}0.6 \\
2.6 \\
1.6 \\
0.8\end{array}$ & $\begin{array}{c}79.6 \\
527 \\
371 \\
88.7\end{array}$ & $\begin{array}{c}122 \\
179 \\
51.8 \\
29.5\end{array}$ & $\begin{array}{c}34.4 \\
191 \\
151 \\
8.4\end{array}$ & $\begin{array}{r}32.8 \\
17.0 \\
1.6 \\
7.1\end{array}$ & & $\begin{array}{r}25 \\
556 \\
471 \\
74\end{array}$ & & $\begin{array}{l}137 \\
145 \\
142\end{array}$ & \begin{tabular}{c|}
103 \\
98.4 \\
101
\end{tabular} & $\begin{array}{l}4.7 \\
4.3 \\
4.8\end{array}$ & $\begin{array}{l}24.4 \\
31.8 \\
29.1\end{array}$ & \begin{tabular}{|l|}
7.20 \\
6.28 \\
7.16
\end{tabular} & $\begin{array}{l}7.44 \\
7.52 \\
7.46\end{array}$ & & \\
\hline $\begin{array}{l}\text { 6) Kat, } \\
550 \mathrm{cc}^{2}, 2.7 \% \\
\text { NaHCO }\end{array}$ & $\begin{array}{l}\text { Supine } \\
\text { Supine } \\
\text { Supine }\end{array}$ & $\begin{array}{l}\underset{\mathbf{A}}{\mathbf{A} * \mathbf{*}} \\
\mathbf{C W}\end{array}$ & $\begin{array}{r}66 \\
104 \\
210\end{array}$ & $\begin{array}{l}1.1 \\
2.0 \\
1.2\end{array}$ & $\begin{array}{l}172 \\
377 \\
253\end{array}$ & $\begin{array}{c}199 \\
206 \\
88.5\end{array}$ & $\begin{array}{l}91.5 \\
200 \\
134\end{array}$ & $\begin{array}{r}38.6 \\
11.3 \\
<1\end{array}$ & & $\begin{array}{l}104 \\
382 \\
298\end{array}$ & & $\begin{array}{l}140 \\
144\end{array}$ & $\begin{array}{l}103 \\
99.7\end{array}$ & $\begin{array}{l}4.3 \\
3.9\end{array}$ & $\begin{array}{l}24.1 \\
28.0\end{array}$ & $\begin{array}{l}7.35 \\
7.50\end{array}$ & $\begin{array}{l}7.43 \\
7.46\end{array}$ & & \\
\hline $\begin{array}{l}\text { 7) Hal, } \\
600 \mathrm{cc}^{3}, 3.1 \% \\
\mathrm{NaHCO}^{2}\end{array}$ & $\begin{array}{l}\text { Supine } \\
\text { Supine } \\
\text { Supine } \\
\text { Supine }\end{array}$ & $\begin{array}{l}\mathbf{A} \\
\mathbf{B}^{*} \\
\mathbf{D} \\
\mathbf{D} W\end{array}$ & $\begin{array}{r}98 \\
63 \\
89 \\
140\end{array}$ & $\begin{array}{l}2.7 \\
6.2 \\
2.8 \\
2.2\end{array}$ & $\begin{array}{l}200 \\
835 \\
373 \\
162\end{array}$ & $\begin{array}{c}259 \\
330 \\
127 \\
35.8\end{array}$ & $\begin{array}{l}113 \\
249 \\
193 \\
103\end{array}$ & $\begin{array}{r}26.6 \\
5.5 \\
2.1 \\
3.4\end{array}$ & & $\begin{array}{l}120 \\
759 \\
441 \\
232\end{array}$ & & $\begin{array}{l}132 \\
139 \\
136\end{array}$ & $\left|\begin{array}{r}95.0 \\
94.0 \\
93.6\end{array}\right|$ & $\begin{array}{l}5.7 \\
5.4 \\
5.1\end{array}$ & $\begin{array}{l}27.6 \\
32.3 \\
32.0\end{array}$ & $\begin{array}{l}7.82 \\
6.96 \\
7.05\end{array}$ & $\begin{array}{l}7.30 \\
7.32 \\
7.40\end{array}$ & & . \\
\hline
\end{tabular}

* Subjects were normal young adults. AVG, DWS (a), Mac, and Kat were thirsting for 12 to 14 hours before the experiments, and were given no water during the experiments except in period marked w. DWS (b), H, and $H a l$ were allowed water ad lib. before the experiments, and drank $100 \mathrm{cc}$. per hour during the experiments. DWS (b) ingested 15 gms. of $\mathrm{NH}_{4} \mathrm{Cl}$ in 36 hours before experiment. This subject also was infused with normal saline containing requisite inulin and sodium para-aminohippurate, at about $2.3 \mathrm{cc}$. per minute throughout the experiment.

$\dagger$ Infusions of test solutes were given during periods marked**. Water p. o. allowed ad lib. in periods marked w. Each period composed of 1 to 3 sub-periods corresponding to individual collections of urine.

$\ddagger$ Serum values at the beginning of each corresponding period, except for values in italics which are at the end of the corresponding period.

8 Changes in plasma volume at the beginning of each corresponding period, calculated with respect to the control period, which is indicated by 0 .

$\| \mathbf{P}$ calculated as $\mathrm{B}_{2} \mathrm{HPO}$.

\# See Experimental Procedure for calculation of anions. 


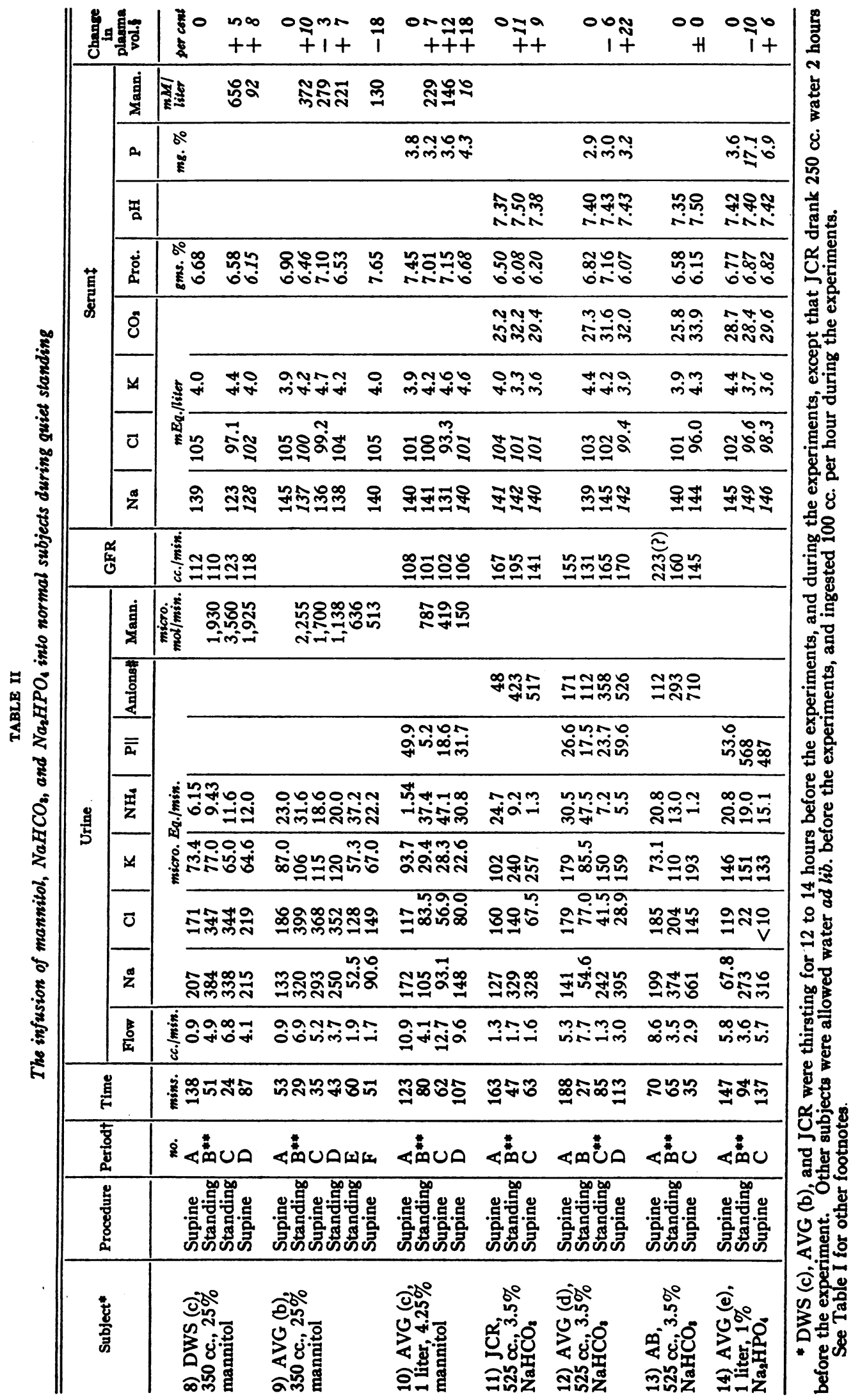


carbonate, this estimate has been found to agree with the measured excretion of bicarbonate with an error of $18 \pm$ 9 per cent.

\section{RESULTS}

\section{Quiet Standing Alone (Table I):}

The effects of quiet standing during hydration and water deprivation were studied in three experiments on two subjects. The passive erect position caused the plasma volume to contract. Urine flow, sodium, potassium and chloride excretion decreased in all experiments, and remained below control values during one or more periods in the supine position. Glomerular filtration decreased in the one experiment in which it was measured. In addition, the excretion of ammonia decreased slightly in the two hydropenic subjects, phosphate excretion was unchanged or declined in two experiments, and the serum bicarbonate decreased slightly, with no significant change in the serum $\mathrm{pH}$ in the two experiments in which it was measured.
Quiet Standing with Mannitol Infusion (Table

II) :

The administration of $350 \mathrm{cc}$. of 25 per cent mannitol to two thirsting subjects (expts. 8 and 9) prevented any significant contraction of the plasma volume. Presumably the transudation of fluid in the lower extremities caused by quiet standing was balanced by the movement of fluid from the tissues into the blood stream, possibly as a result of two mechanisms : (a) the extraction of water from cells (indicated by the decrease in the serum sodium), and its distribution to the plasma volume as a part of the extracellular space; and (b) the withdrawal of fluid from the extracellular fluid into the blood, as a result of the transient osmotic gradient set up during diffusion of mannitol from the vascular compartment.

Glomerular filtration was also maintained at control values during the period of quiet standing in experiment 8.

The excretion of water, sodium, and chloride

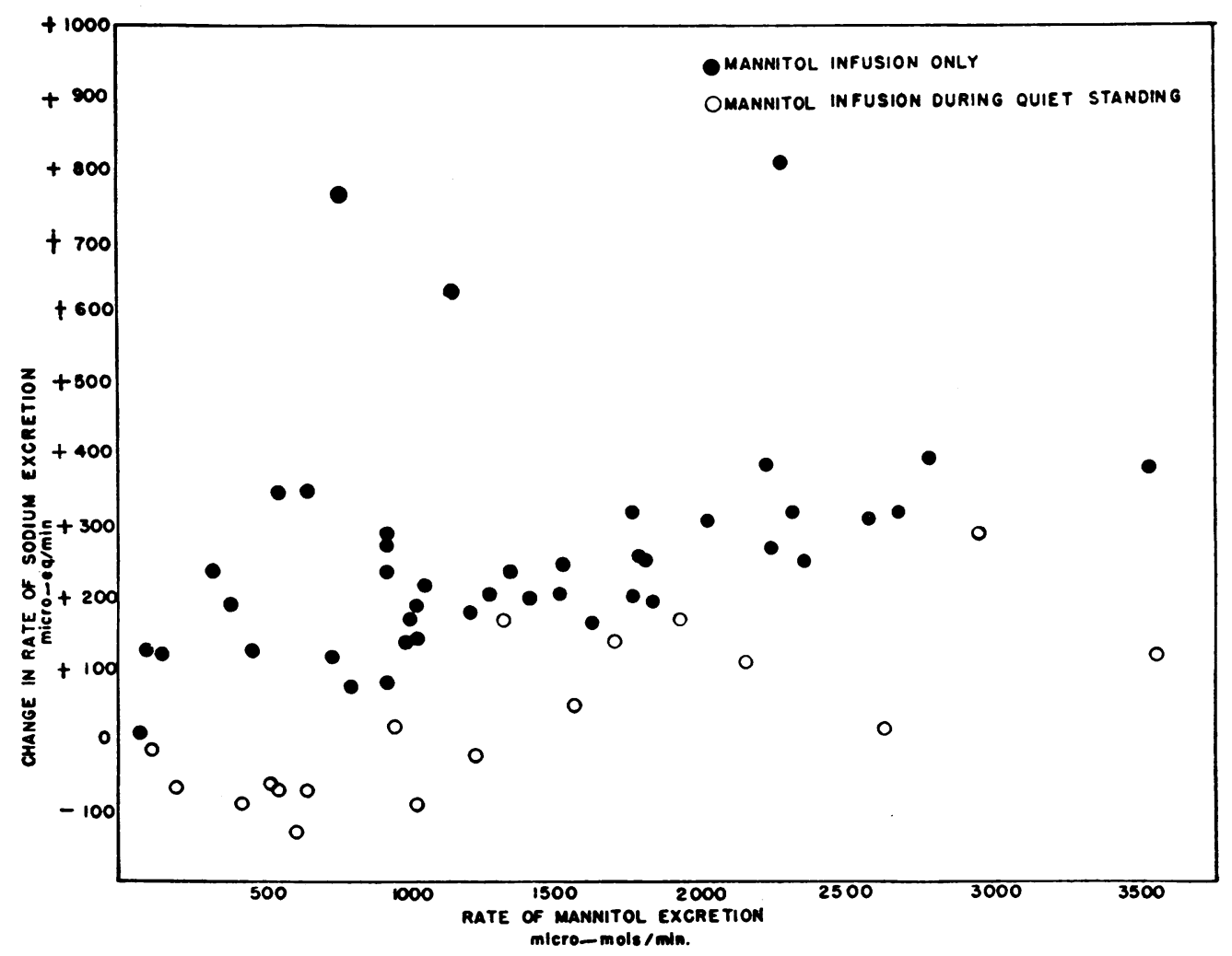

Fig. 1. Changes in the Rate of Excretion of Sodium Compared with the Rates of ExCretion of Mannitol CaUsed by Infustons of Mannitol

Individual periods of urine collection. Data concerning the infusion of mannitol only, taken from seven experiments in part previously reported $(2,20)$. 
TABLE III

Modification of the decrease in sodium excrelion during quiet standing by infusions of sodium salts

\begin{tabular}{|c|c|c|c|}
\hline $\begin{array}{l}\text { Infusion given during } \\
\text { quiet standing }\end{array}$ & $\begin{array}{l}\text { No. of } \\
\text { obser- } \\
\text { vations }\end{array}$ & $\begin{array}{c}\text { Mean } \\
\text { change* } \\
\text { in sodium } \\
\text { excretion } \\
\text { micro. } \\
\text { Eq./min. }\end{array}$ & $\begin{array}{c}\text { Range* } \\
\text { micro. Eq./min. }\end{array}$ \\
\hline $\begin{array}{l}\text { None** } \\
400 \mathrm{cc}, 3-4 \% \mathrm{NaCl}^{* *} \\
400 \mathrm{cc}, 6 \% \mathrm{NaCl}^{* *} \\
500 \mathrm{cc}, 3.6 \% \mathrm{NaHCO}_{2} \\
1,000 \text { cc., isotonic, }\end{array}$ & $\begin{array}{l}6 \\
2 \\
4 \\
3\end{array}$ & $\begin{array}{r}-91 \\
-101 \\
-41 \\
+140\end{array}$ & $\begin{array}{l}-39 \text { to }-243 \\
-30 \text { to }-172 \\
+273 \text { to }-149 \\
+228 \text { to }+117\end{array}$ \\
\hline phosphate & 1 & +209 & - \\
\hline
\end{tabular}

* Values calculated as the differences between the average rates of 1-3 control periods, and the rates of 1-2 experimental periods.

** Data of 3 of the experiments without infusions, and of all the experiments with $\mathrm{NaCl}$ infusions, were taken from another study (4).

increased during the infusion of mannitol and for several periods thereafter (expts. 8 and 9). However, it is evident from Figure 1 that quiet standing in these experiments limited the usual increase in excretion of sodium which is caused in the nor- mal subject by the infusion of mannitol. Indeed, in one of the experiments (expt. 9, Table II), sodium excretion decreased below control values during a second period of quiet standing and then increased again when the subject was supine, although the excretion of mannitol continued slowly to decline.

In a third experiment, on a hydrated subject (expt. 10, Table II), the injection of a smaller quantity of mannitol maintained glomerular filtration at control values, and the plasma volume at or above control values, but sodium excretion declined below control values despite a mannitol diuresis which would have induced marked losses of sodium, if the subject had been supine.

Quiet Standing with the Infusion of $\mathrm{NaHCO}_{3}$ or $\mathrm{Na}_{2} \mathrm{HPO}_{4}$ :

Control Studies: The infusion of $18.75 \mathrm{gms}$. of $\mathrm{NaHCO}_{3}$ as a 3 per cent solution into normal supine subjects augmented greatly the excretion of water, sodium, and potassium. Chloride ex-

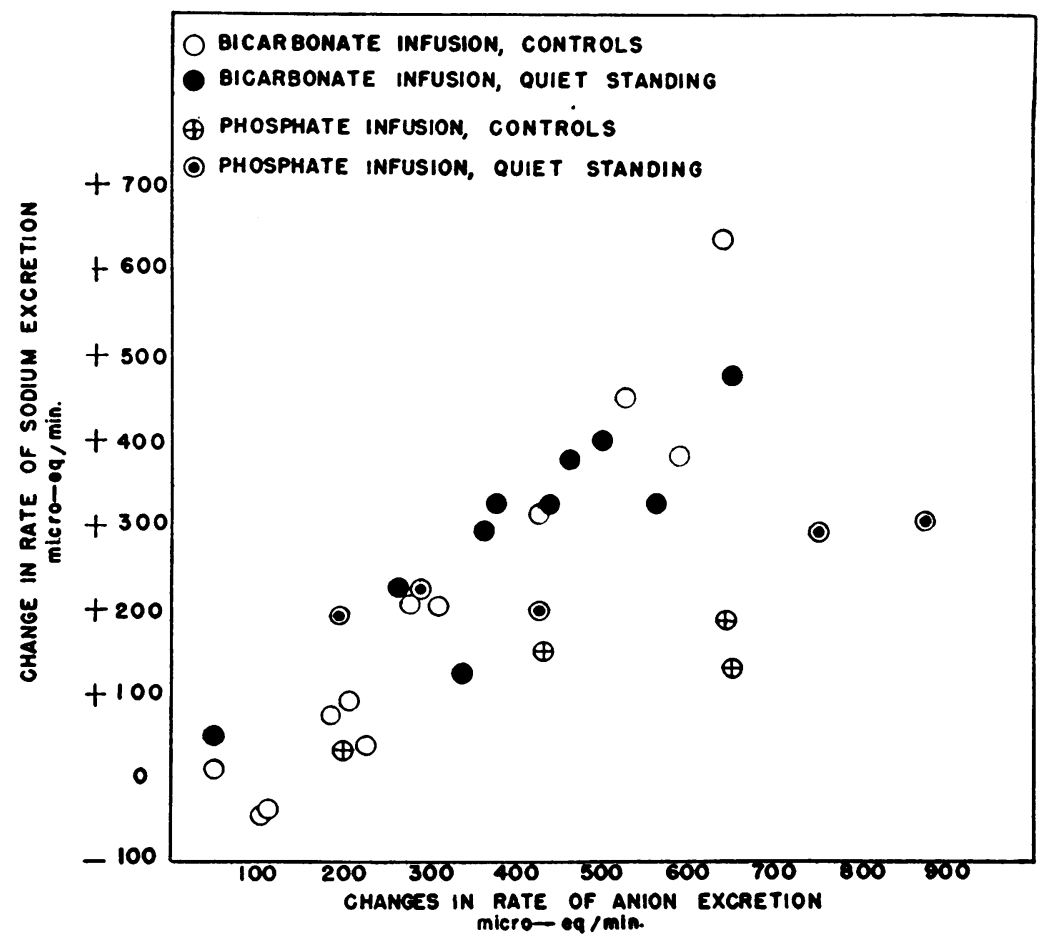

Fig. 2. Changes in the Rate of Excretion of Sodium Compared with Changes in the Rate of Excretion of Anions Caused by the Infusion OF $\mathrm{NAHCO}_{3}$ AND $\mathrm{NA}_{2} \mathrm{HPO}_{4}$

Individual periods of urine collection. 
cretion initially increased, but then decreased. Ammonia excretion uniformly declined. The concentrations of bicarbonate and sodium in the serum increased; those of chloride and protein decreased.

The infusion of one liter of isotonic $\mathrm{Na}_{2} \mathrm{HPO}_{4}$ into one normal subject increased greatly the excretion of sodium and potassium, increased slightly the excretion of ammonia, and decreased the excretion of chloride. The concentrations of chloride and protein in the serum decreased slightly, that of phosphate increased greatly.

Studies with Quiet Standing: Injections of sodium bicarbonate and buffered sodium phosphate prevented any significant fall of plasma volume, in three of four experiments (expts. 11, 12, 13), or of glomerular filtration rate in two experiments (expts. 11 and 12). However, sodium excretion was augmented in the same manner during quiet standing as in the supine position in each experiment (Figure 2). This was in sharp contrast to the inhibition of sodium excretion caused by the passive erect posture during mannitol loading (described above) and during salt loading (Table III). In the latter Table, various sodium salts are compared for their effects on the usual retention of sodium induced by quiet standing. Although the excretion of sodium decreased during quiet standing in spite of infusions of sodium chloride (except in one experiment with 6 per cent saline), it increased in all experiments in which sodium bicarbonate or phosphate was infused. Potassium excretion was augmented by the administration of sodium bicarbonate during quiet standing, as in control studies, but was not appreciably changed by infusions of sodium phosphate.

\section{DISCUSSION}

\section{A. Infusions of Mannitol}

In the present experiments on normal subjects during quiet standing, as in previous experiments on patients with edema $(6,20)$, the sodium diuresis induced by mannitol loads was partially inhibited (Figure 1). Since glomerular filtration rate remained at or above control values (expts. 8 and 10) the inhibition of sodium diuresis appeared to be the result of an increased capacity of the renal tubules to reabsorb sodium. This conclusion is in doubt only to the extent that the estimation of glomerular filtration by present clearance methods is not sufficiently accurate to define the exact relationship between a small (unmeasurable) fall in the filtered sodium and a change in the tubular reabsorption of this ion.

The results do not imply that the renal responses to infused solutes are not mediated at least in part by the direct effect of a change in the solute content and flow of the tubular fluid (3). They do emphasize, however, that internal regulatory mechanisms in normal subjects, as in patients with edema, may be of sufficient intensity to limit the intratubular effects of an administered solute on the reabsorption of sodium. What specific regulatory mechanisms are involved, and whether they may apply to the state of edema, are questions concerning which only inferential data are now available.

In the present experiments, several factors of the internal environment were considered possible stimuli for the retention of sodium:

1. Changes in the serum sodium (Table II), and calculated internal shifts of water and electrolytes were not significantly different during quiet standing from those in previously reported experiments in which mannitol was administered in the supine position (2). In experiments 8 and 9, when hypertonic mannitol was infused, intracellular balances of water and potassium were negative. Positive values for sodium were too small to be considered significant. In experiment 10 , when 4.25 per cent mannitol was infused, intracellular balances of water, sodium, and potassium were not significantly altered.

2. Support of the total plasma volume in these experiments by the infusion of mannitol, as in other similar studies by the infusion of albumin (9), failed to eliminate the stimulus for salt retention (Figure 1) elicited by standing. These infusions, however, undoubtedly did not prevent local pooling of blood (in the lower extremities), transudation in the area of increased venous pressure, and consequent redistribution of the flow and volume of the circulating blood. The importance of these factors in the control of salt excretion may be inferred from studies of other abnormal circulatory states in which they may also be operative : Sodium retention occurs with the venous congestion produced by tourniquets on the limbs (21) 
or by obstruction of the inferior vena cava (22, 23) and with the portal congestion of decompensated hepatic cirrhosis (24) just as it does when a large volume of blood is actually removed from the circulation by hemorrhage (25). With venous obstruction, cardiac output and arterial blood pressure tend to fall (26). The renal response occurs in spite of lumbodorsal sympathectomy (21) and is independent of the pituitary (27), the adrenals (28) or of measurable circulatory changes in the kidney, but it may be eliminated by very large blood transfusions (26) (which probably overcompensate for blood lost by pooling). The upright position causes vasoconstriction in the cerebral (29) and splanchnic (30) areas; the renal response may occur in the absence of the adrenals (31).

It is possible, therefore, that in the present experiments, although there was no hemoconcentration when mannitol was infused during quiet standing, the kidneys may have responded not to the circulating blood volume as a whole, but to a change in the flow and/or volume of blood in some "central" area of the circulation $(32,33)$.

\section{B. Infusions of Sodium Bicarbonate and Phosphate}

In order to determine more precisely the intensity and character of the increased tubular capacity for sodium transport which is induced by quiet standing, sodium bicarbonate and buffered sodium phosphate were injected in experiments 11 to 14 . These salts impose unique limitations on the tubular reabsorption of sodium. When the anion of an administered electrolyte is reabsorbed only to a slight extent, the total excretion of cations into the urine is correspondingly increased because of the limited quantity of free acid which may be secreted by the tubules." The factors which determine the nature of the "covering" cation are unclear, but under ordinary conditions, particularly when the administered electrolyte is a sodium salt, this cation is mostly sodium. In the presence of a strong stimulus for the retention of sodium, it might be expected that the increased cation would be largely potassium (or conceivably partly am-

- This limitation is imposed not only because of the extreme acidity of acids such as $\mathrm{H}_{3} \mathrm{PO}_{4}$ and $\mathrm{H}_{2} \mathrm{SO}_{4}$, but also, in the case of bicarbonate, because of the probability that $\mathrm{CO}_{2}$ has a great capacity to diffuse back rapidly across the tubular membrane. monium, in the case of phosphate or sulfate). Indeed, when sodium bicarbonate is administered to patients with congestive heart failure or with "decompensated" hepatic cirrhosis, the bicarbonate ion is excreted to a great extent with potassium (20). However, in the present experiments, injected sodium bicarbonate and sodium phosphate were excreted much more easily during quiet standing than were similar quantities of sodium chloride which were of about the same tonicity and which increased the serum sodium to approximately the same extent (Table III). Furthermore, standing did not alter the role of sodium as the chief "covering" cation in the urine (Figure 2). The increased excretion of potassium was similar to that which was observed in the absence of a stimulus for the retention of sodium.

Two explanations for these results suggest themselves: (1) the effects of administered phosphate or bicarbonate on the excretion of sodium involve renal tubular mechanisms which may be entirely distinct in location (proximal vs. distal) or character (ion exchange vs. trace resorption) from those involved in the sodium retention of quiet standing; or (2) the stimulus for sodium retention imposed by quiet standing is not sufficiently powerful to counteract the unique limitation imposed by the excretion of bicarbonate and phosphate on the reabsorption of sodium. It may be that the excretion of sodium bicarbonate would be curtailed in the normal subject, as it is in the patient with edema $(20,34-36)$, if the stimulus for the retention of sodium were intense enough and sufficiently prolonged.

\section{SUMMARY}

Infusions of mannitol, sodium bicarbonate and sodium phosphate were administered to normal subjects in the supine position and during quiet standing.

Observations were made of changes in the plasma volume, the serum electrolytes, and the urinary excretion of the loading solute, and of sodium and other electrolytes.

It was found that quiet standing partially inhibited the sodium diuresis induced by the administration of mannitol, but did not interfere with the increased excretion of sodium caused by infusions of $\mathrm{NaHCO}_{3}$ or $\mathrm{Na}_{2} \mathrm{HPO}_{4}$. 
The results with mannitol indicate the operation of internal regulatory mechanisms on the intrinsic renal responses which characterize solute diuresis.

The results with sodium bicarbonate and phosphate are discussed in relation to the unique limitations imposed by these salts on the tubular reabsorption of sodium.

\section{REFERENCES}

1. Relman, A. S., Goodyer, A. V. N., and Peterson, E. $R$., Effect of mannitol on salt excretion during water diuresis. J. Applied Physiol., 1949, 1, 601.

2. Seldin, D. W., and Tarail, R., Effect of hypertonic solutions on metabolism and excretion of electrolytes. Am. J. Physiol., 1949, 159, 160.

3. Goodyer, A. V. N., and Glenn, W. W. L., Excretion of solutes injected into the renal artery of the dog. Am. J. Physiol., 1952, 168, 66.

4. Wesson, L. G., Jr., and Anslow, W. P., Jr., Excretion of sodium and water during osmotic diuresis in the dog. Am. J. Physiol., 1948, 153, 465.

5. Seldin, D. W., and Welt, L. G., Unpublished studies.

6. Tarail, R., Seldin, D. W., and Goodyer, A. V. N., Effects of injection of hypertonic glucose on metabolism of water and electrolytes in patients with edema. J. Clin. Invest., 1951, 30, 1111.

7. White, H. L., Rosen, I. T., Fischer, S. S., and Wood, G. H., The influence of posture on renal activity. Am. J. Physiol., 1926, 78, 185.

8. Brun, C., Knudsen, E. O. E., and Raaschou, F., The influence of posture on the kidney function. Acta. med. Scandinav., 1945, 122, 332 and 486.

9. Epstein, F. H., Goodyer, A. V. N., Lawrason, F. D., and Relman, A. S., Studies of the antidiuresis of quiet standing : the importance of changes in plasma volume and glomerular filtration rate. $\mathrm{J}$. Clin. Invest., 1951, 30, 63.

10. Ollayos, R. W., and Winkler, A. W., Urinary excretion and serum concentration of inorganic phosphate in man. J. Clin. Invest., 1943, 22, 147.

11. Smith, W. W., Finklestein, N., and Smith, H. W., Renal excretion of hexitols (sorbitol, mannitol, and dulcitol) and their derivatives (sorbitan, isomannide, and sorbide) and of endogenous creatininelike chromogen in dog and man. J. Biol. Chem., 1940, 135, 231.

12. Elkinton, J. R., The volume of distribution of mannitol as a measure of the volume of extracellular fluid, with a study of the mannitol method. J. Clin. Invest., 1947, 26, 1088.

13. Roe, J. H., Epstein, J. H., and Goldstein, N. P., A photometric method for the determination of inulin in plasma and urine. J. Biol. Chem., 1949, 178, 839.

14. Fiske, C. H., and Subbarow, Y., The colorimetric determination of phosphorus. J. Biol. Chem., 1925, 66, 375 .
15. Hald, P. M., in Peters, J. P., and Van Slyke, D. D., Quantitative Clinical Chemistry, Vol. II, Methods, p. 838. Williams and Wilkins, Baltimore, 1932.

16. Gornall, A. G., Bardawill, C. J., and David, M. M., Determination of serum proteins by means of the biuret reaction. J. Biol. Chem., 1949, 177, 751.

17. Van Slyke, D. D., and Neill, J. M., in Peters, J. P., and Van Slyke, D. D., Quantitative Clinical Chemistry, Vol. II, Methods. Williams and Wilkins, Baltimore, 1932.

18. Conway, E. J., Microdiffusion Analysis and Volumetric Error. Crosby Lockwood \& Son, Ltd., London, 1947.

19. Harvey, S. C., The quantitative determination of the chlorids in the urine. Arch. Int. Med., 1910, 6, 12.

20. Goodyer, A. V. N., and Seldin, D. W., Studies to be published.

21. Wilkins, R. W., Culbertson, J. W., Burrows, B. A., Tinsley, C. M., Judson, W. E., and Burnett, C. H., Antidiuresis and renal vasoconstriction following venous congestion of the limbs in normal, hypertensive, and splanchnicectomized subjects. J. Clin. Invest., 1949, 28, 819.

22. Farber, S. J., Alexander, J. D., and Eichna, L. W., Renal hemodynamics and salt and water excretion during induced congestion of inferior vena cava of man. J. Clin. Invest., 1951, 30, 638.

23. Frieden, J., Rice, L., Elisberg, E. I., Eisenstein, B., and Katz, L. N., Effects of chronic peripheral venous congestion on renal sodium excretion. Am. J. Physiol., 1952, 168, 650.

24. Goodyer, A. V. N., Relman, A. S., Lawrason, F. D., and Epstein, F. H., Salt retention in cirrhosis of the liver. J. Clin. Invest., 1950, 29, 973.

25. Lombardo, T. A., Eisenberg, S., Oliver, B. B., Viar, W. N., Eddleman, E. E., Jr., and Harrison, T. R., Effects of bleeding on electrolyte excretion and on glomerular filtration. Circulation, 1951, 3, 260.

26. Judson, W. E., Hatcher, J. D., Halperin, M. H., and Wilkins, R. W., Further studies on the antidiuresis and decrease in sodium excretion during venous congestion of the limbs: its prevention in normal subjects by a large transfusion; its absence or presence in cardiac patients with or without congestive failure. J. Clin. Invest., 1952, 31, 642.

27. Judson, W. E., Epstein, F. H., Tinsley, C. M., Burrows, B. A., and Wilkins, R. W., The hemodynamic and renal functional effects of venous congestion of the limbs in patients with diabetes insipidus. J. Clin. Invest., 1950, 29, 826.

28. Rosenbaum, J. D., Papper, S., and Ashley, M. M., Variations in renal tubular reabsorption of sodium independent of change in adrenocortical hormone. J. Clin. Invest., 1952, 31, 657.

29. Patterson, J. L., Jr., and Warren, J. V., Mechanisms of adjustment in the cerebral circulation upon assumption of the upright position. J. Clin. Invest., 1952, 31, 653.

30. Culbertson, J. W., Wilkins, R. W., Ingelfinger, F. J., 
and Bradley, S. E., The effect of the upright posture upon hepatic blood flow in normotensive and hypertensive subjects. J. Clin. Invest., 1951, 30, 305.

31. Holland, B. C., Effects of head-up tilting, pitressin, ACTH, cortisone and desoxycorticosterone glucoside on excretion of sodium and chloride. $\mathrm{J}$. Clin. Invest., 1952, 31, 639.

32. Lewis, J. M., Jr., Buie, R. M., Sevier, S. M., and Harrison, T. R., The effect of posture and of congestion of the head on sodium excretion in normal subjects. Circulation, 1950, 2, 822.

33. Viar, W. N., Oliver, B. B., Eisenberg, S., Lombardo, T. A., Willis, K., and Harrison, T. R., The effect of posture and of compression of the neck on excretion of electrolytes and glomerular filtration: further studies. Circulation, 1951, 3, 105.
34. Albright, F., and Bauer, W., The action of sodium chloride, ammonium chloride, and sodium bicarbonate on the total acid-base balance of a case of chronic nephritis with edema. J. Clin. Invest., 1929, $7,465$.

35. Burnett, G. H., Burrows, B. A., and Commons, R. R., The lack of correlation between glomerular filtration rate, and serum electrolyte concentration changes, urinary electrolyte excretion, or edema formation following sodium loads in subjects with normal kidneys, glomerulonephritis, and the nephrotic syndrome. J. Clin. Invest., 1949, 28, 773.

36. Corson, S. A., O'Leary, E., Spellman, M. W., Siegel, A. L., and Harrison, E., Diuretic effects of sodium salts of organic acids in patients with cardiac and nephrotic edema. Fed. Proc., 1949, 9, 25. 